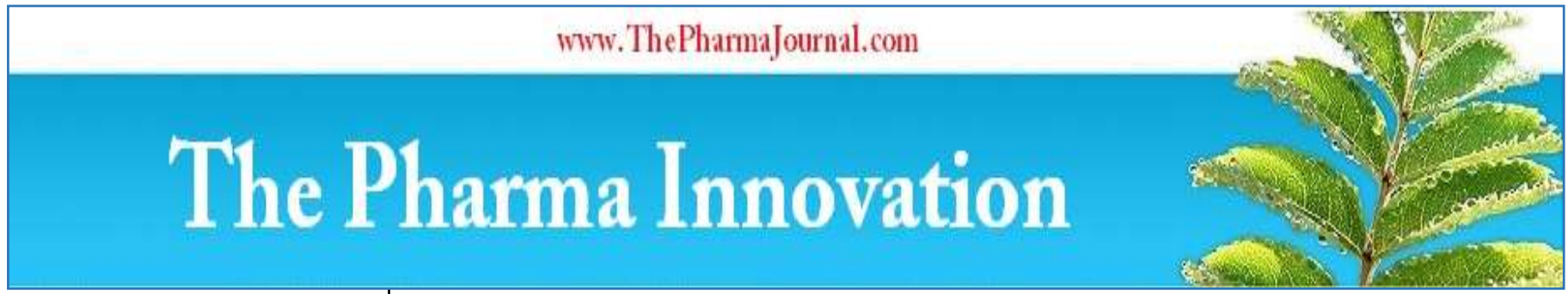

ISSN (E): 2277- 7695

ISSN (P): 2349-8242

NAAS Rating: $\mathbf{5 . 2 3}$

TPI 2021; 10(3): 107-113

(C) 2021 TPI

www.thepharmajournal.com

Received: 11-01-2021

Accepted: 17-02-2021

Aswalekar KG

Department of Food

Microbiology and Safety, Rajiv

Gandhi College of Food

Technology, Parbhani.

Maharashtra, India

Katke SD

Department of Food

Microbiology and Safety, College

of Food Technology, VNMKV,

Parbhani, Maharashtra, India

Pandhare GR

Dept. of Chemical Technology,

Dr. Babasaheb Ambedkar

Marathwada University,

Aurangabad, Maharashtra, India

Corresponding Author:

Aswalekar KG

Department of Food

Microbiology and Safety, Rajiv

Gandhi College of Food

Technology, Parbhani,

Maharashtra, India

\section{Studies on formulation and quality evaluation of weaning food from sorghum malt}

\author{
Aswalekar KG, Katke SD and Pandhare GR
}

DOI: https://doi.org/10.22271/tpi.2021.v10.i3b.5924

\begin{abstract}
In the present investigation attempts have been made to prepare weaning food having low cost, high nutritional value, low viscosity and better acceptability by using sorghum malt. Three weaning foods combination were prepared by using different proportions of sorghum malt flour, mothbean malt flour, sesame flour and skim milk powder. These formulations were subjected to organoleptic evaluation and among the experimental formulations, formulation $\mathrm{F}_{1}$ containing sorghum malt, mothbean malt, sesame flour and skim milk powder in the proportion of 50:30:10:10 was accepted as best considering the highest sensory score (8.28) awarded to it.
\end{abstract}

Keywords: Weaning food, sorghum malt, malt flour, mothbean malt, sesame flour, skim milk powder

\section{Introduction}

Cereals constitute by far the most important group of food stuff as they form the staple food of a large majority of the population throughout the world. They form 70 to $80 \%$ of the diets of the low income groups in India. They provide 70 to $80 \%$ of the calories and proteins in the diet of low income groups (Swaminathan, 1996) ${ }^{[20]}$. Sorghum (Sorghum bicolor (L.) Moench) is the most important cereal crop grown largely under rainfed conditions in the semiarid tropics of Asia, Africa and the Americas. India is the second largest producer of sorghum in the world, the yield of $840 \mathrm{~kg}$ per hectare is the lowest amongst the major sorghum-producing countries in the world. The world average is $1435 \mathrm{~kg}$ per hectare. Although yield of sorghum in India is much lower than the world average, it has been consistently increasing during the recent past. Sorghum is the third important grain crop in India, next only to rice and wheat. Maharashtra, Karnataka, Madhya Pradesh, Andhra Pradesh and Rajasthan are the principle sorghum growing states of India. The total production was 3.850 MMT during the year 2019-20. Syed Ismail et al. (2000) ${ }^{[21]}$ described the nutritional composition of sorghum grains of different varieties produced at Parbhani, Maharashtra and India. The values were found in the range as protein 9.13 to $11 \%$, starch 68.32 to $72.33 \%$, crude fat 1.69 to $2.88 \%$, crude fibre 1.75 to $2.86 \%$, ash 1.71 to $2.85 \%$ and energy value 345 to $356 \mathrm{cal} / 100 \mathrm{~g}$. Malting of grain sorghum has been reported to increase the water soluble protein, lysine, methionine, soluble sugars (Bhise et al., 1988) ${ }^{[6]}$.

Weaning is a process by which foods other than breast milk are introduced into the diet of an infant when the infant is no longer satisfied with milk alone. Up to 4 to 6 months of age breast milk is enough to satisfy nutritional demands of the child, but after that supplementary foods should be started. Protein energy malnutrition generally occurs during the crucial transitional phase when children are weaned from liquid to semisolid or fully adult foods. During this period, because of their rapid growth, children need nutritionally balanced, calories dense supplementary foods in addition to mother's milk (Berggren, 1982) ${ }^{[4]}$. The usefulness of weaning foods to meet the needs of children being weaned from a liquid milk based diet, to a solid or semi solid diet is now well recognized and the several weaning foods have been developed in different parts of the world. Such foods should be nutritionally well balanced and should have a soft texture with very low fibre content. Most weaning foods marketed in developing countries are produced by roller drying or extrusion cooking. These are capital intensive technologies and the foods produced have a large dietary bulk that limits children's nutrient intake. It is therefore desirable to develop low cost weaning foods from locally available resources adopting simple technologies, so that the foods can be produced by mothers, community workers, or government agencies and supplied at low cost. 
One of the simple traditional technologies that are being adopted for weaning food is the malting of cereals and legumes. Malting not only enhances their overall nutritional qualities but also allows preparation of low-bulk foods (Wondimu and Malleshi, 1996) ${ }^{[25]}$. Though, the commercially manufactured weaning foods are available in Indian market, these are very expensive, starchy, gelatinized and have a high paste viscosity which limits the total food intake by child. In developing countries there is need to develop low cost, low paste viscosity, high calorie density weaning food based on simple technology using locally available raw materials like cereals, legumes and oil seeds.

\section{Materials and Method}

\section{Procurement of Raw Materials}

Sorghum (Sorghum bicolor (L.) Moench), Mothbean (Phaseolus aconitifolius), Sesame seed (Sesamum indicum) and skim milk powder was purchased from the local market

\section{Processing of raw materials}

The Malted flour of sorghum, mothbean; and sesame flour were prepared as per the method described by Kulkarni et al., (1991) ${ }^{[12]}$. The processing techniques used for preparation of malt and sesame flour are shown in Flowsheet 1

$\begin{array}{ccc}\text { Sorghum } & \text { Mothbean } & \text { Sesame kernels } \\ \downarrow & \downarrow & \downarrow \\ \text { Cleaning } & \text { Cleaning } & \text { Cleaning } \\ \downarrow & \downarrow & \downarrow \\ \text { Steeping } 18 \mathrm{hr} & \text { Steeping } 12 \mathrm{hr} & \text { Dipping in hot water } \\ \downarrow & \downarrow & \downarrow \\ \text { Germination } 72 \mathrm{hr} & \text { Germination } 24 \mathrm{hr} & 5 \% \text { NaOH treatment, } \\ \text { at } 20^{\circ} \mathrm{C} & \text { at } 20^{\circ} \mathrm{C} & 90 \text { sec. } \\ 95 \% \text { RH } & 95 \% \mathrm{RH} & \downarrow \\ \downarrow & \downarrow & \text { Hot water rinse } \\ \text { Drying at 55 } 55^{\circ} \mathrm{C} & \text { Drying } & \downarrow \\ \downarrow & \downarrow & 5 \% \text { acetic acid } \\ \text { Separation of } & \text { Separation of } & \text { treatment } \\ \text { sprouts } & \text { husks } & \downarrow \\ \downarrow & \downarrow & \downarrow \\ \text { Grinding } & \text { Grinding } & \text { Discarding seed coat } \\ \downarrow & \downarrow & \downarrow \\ \text { Sieving } & \text { Sieving } & \text { Roasting } \\ \downarrow & \downarrow & \downarrow \\ \text { Sorghum malt } & \text { mothbean } & \text { Milling in hammer } \\ \text { flour } & \text { malt flour } & \text { mill } \\ & & \downarrow\end{array}$

Flow Sheet 1: Processing of raw materials

Development of weaning food

Three weaning foods combinations were prepared by using different proportions of sorghum malt flour, mothbean malt flour, sesame flour and skim milk powder. The proportion is shown in Table 1

Table 1: Recipe formulation for weaning food

\begin{tabular}{|c|c|c|c|c|}
\hline $\begin{array}{c}\text { Recipe } \\
\text { formulation }\end{array}$ & $\begin{array}{c}\text { Sorghum } \\
\text { malt flour } \\
(\mathbf{g})\end{array}$ & $\begin{array}{c}\text { Mothbean } \\
\text { malt flour } \\
(\mathbf{g})\end{array}$ & $\begin{array}{c}\text { Sesame } \\
\text { Flour } \\
(\mathbf{g})\end{array}$ & $\begin{array}{c}\text { Skim } \\
\text { milk } \\
\text { Powder } \\
(\mathbf{g})\end{array}$ \\
\hline $\mathrm{F}_{1}$ & 50 & 30 & 10 & 10 \\
\hline $\mathrm{F}_{2}$ & 60 & 20 & 10 & 10 \\
\hline $\mathrm{F}_{3}$ & 70 & 10 & 10 & 10 \\
\hline
\end{tabular}

\section{Preparation of Weaning Food Mix}

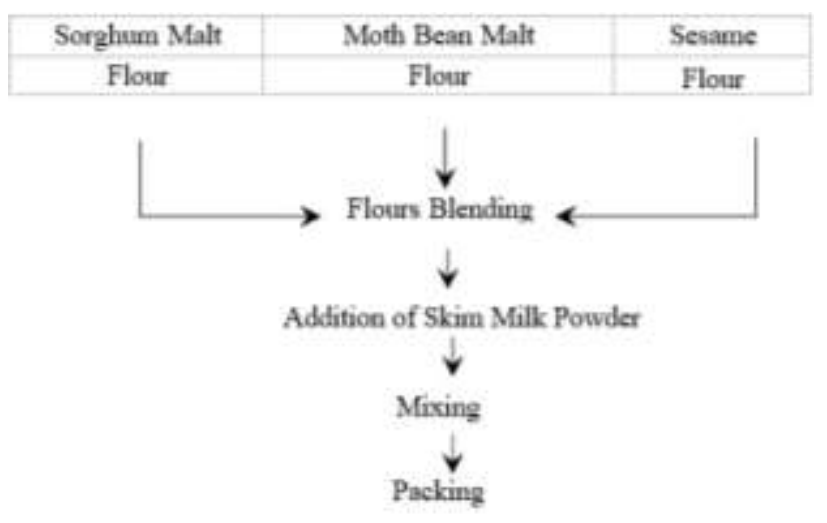

Flow Sheet 2: Preparation of weaning food mix

Preparation of Weaning Food

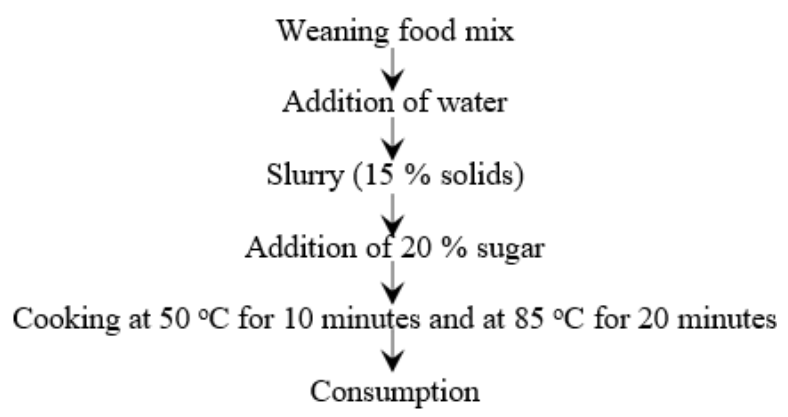

Flow Sheet 3: Preparation of weaning food

\section{Results and Discussion}

\section{Proximate composition of raw material}

Proximate composition of sorghum, moth bean, sesame and skim milk powder were estimated. The results emerged out are presented in Table 2 .

Table 2: Proximate composition of raw material

\begin{tabular}{|c|c|c|c|c|}
\hline Constituents (\%) & Sorghum & Mothbean & Sesame & Skim milk powder \\
\hline Moisture & 9.45 & 8.51 & 5.01 & 4.21 \\
\hline Crude fat & 2.54 & 3.20 & 45.50 & 0.10 \\
\hline Crude protein & 10.04 & 25.42 & 22.57 & 35.00 \\
\hline Total Carbohydrates & 74.12 & 58.10 & 26.35 & 54.10 \\
\hline Crude fibre & 1.80 & 3.20 & 2.40 & --- \\
\hline Ash & 1.44 & 3.10 & 3.60 & --- \\
\hline
\end{tabular}

The data indicates that sorghum contained the maximum amount of total carbohydrates $(74.12 \%)$, whereas among the grain samples the highest content of protein was observed in mothbean $(25.42 \%)$ followed by sesame (22.57\%). Being a cereal crop content of protein in sorghum was 10.04. However, the crude fat was found to the tune of 45.50 per cent in sesame (oilseed), and very small amount of crude fat i.e., 3.20 per cent and 2.54 per cent was noted in mothbean 
and sorghum respectively. Further the total mineral content (ash) was found maximum in sesame $(3.60 \%)$ followed by mothbean $(3.10 \%)$ and sorghum $(1.44 \%)$. Crude fibre was also determined which was noted 3.20 per cent in mothbean, 2.40 per cent in sesame and 1.80 per cent in sorghum. Similar observation related to proximate composition of sorghum were reported by Syed Ismail et al. (2000) ${ }^{[21]}$, Wankhede et al. (2000) [23] and Laxmi Tulasi (2003) ${ }^{[13]}$. Similar observations related to proximate composition of sesame were also reported by Kulkarni (1994) ${ }^{[11]}$. However, Tokusoglu et al. (2004) ${ }^{[22]}$ reported protein and crude oil in similar range, but they reported carbohydrates in very negligible quantity i.e., 5.24 to 9.47 and justified that this might be due to reflection of varietals character and environmental effects. The results are in good conformity with the proximate composition as reported by Gopalan et al. (2002) ${ }^{[9]}$. The proximate composition of skim milk powder was also estimated. Skim milk powder was found rich in total carbohydrates $(54.10 \%)$ and crude protein $(35.00 \%)$.

\section{Effect of processing of raw material on the proximate composition}

Sorghum and mothbean grains were processed for malting and sesame seeds were dehusked adopting standard procedures. The changes observed during processing are presented in Table 3 and 4

\section{Malting of sorghum}

Table 3: Chemical composition of sorghum and malted sorghum

\begin{tabular}{|c|c|c|}
\hline Constituents & Sorghum & Malted Sorghum \\
\hline Moisture (\%) & 9.45 & 8.01 \\
\hline Crude fat (\%) & 2.54 & 2.53 \\
\hline Crude protein (\%) & 10.04 & 10.10 \\
\hline Total carbohydrates (\%) & 74.12 & 72.00 \\
\hline Crude fibre (\%) & 1.80 & 1.80 \\
\hline Ash (\%) & 1.44 & 1.12 \\
\hline Available lysine g/16 g N & 2.50 & 3.24 \\
\hline In-vitro protein digestibility (\%) & 80.90 & 83.50 \\
\hline $\begin{array}{c}\text { In-vitro starch digestibility } \\
\text { (Mg maltose/g/2hr.) }\end{array}$ & 137.80 & 140.30 \\
\hline Malting loss (\%) & -- & $19.40 \%$ \\
\hline
\end{tabular}

Malting of sorghum resulted slight increase in protein content but total carbohydrates were decreased from 74.12 to 72.00 per cent. Desirable nutritional changes were found to occur improving content of lysine, IVPD and IVSD. Available lysine was increased from 2.50 to $3.24 \mathrm{~g} / 16 \mathrm{~g} \mathrm{~N}$, IVPD improved from 80.90 to 83.40 per cent and IVSD 137.80 to $140.30 \mathrm{mg}$ maltose $/ \mathrm{g} / 2 \mathrm{hr}$. However, there was loss of 19.40 per cent due to malting. The difference in weight of grains before steeping and after drying of germinated grain was taken as malting loss (Bodhankar, 1992) ${ }^{[7]}$. The increase in IVPD is due to the hydrolysis of storage proteins of cereals by proteolytic enzymes leading to increase in water soluble proteins and free amino acids during malting, such partially hydrolyzed storage proteins may be more easily available for pepsin attack (Bhise et al., 1988) ${ }^{[6]}$.

$\mathrm{Wu}$ and Wall (1980) ${ }^{[26]}$ reported that there was little difference in protein content during the first three days of germination of sorghum grains. For the first three days of sprouting a small increase occurred in lysine, methionine and cystine content. The per cent protein was found to be increased as a result of dry matter loss in the grain during germination. During malting the ash content of sorghum was reduced from 1.44 to 1.12 per cent. This decrease can be attributed to leaching losses during soaking and rinsing. Bhise et al. (1988) ${ }^{[6]}$ reported the same results for protein, IVPD, carbohydrate and ash.

Malleshi and Desikachar (1986) ${ }^{[15,17]}$ reported the changes in lysine, tryptophan, threonine and methionine during sprouting of millets. Significant increase in lysine and tryptophan contents were observed in all the millets after $48 \mathrm{hr}$. of sprouting.

\section{Malting of mothbean}

Malting of mothbean also improved the nutritional quality but to very negligible extent. The changes in the nutrient contents are given in Table 4.

Table 4: Chemical composition of mothbean and malted mothbean

\begin{tabular}{|c|c|c|}
\hline Constituents & Mothbean & Malted mothbean \\
\hline Moisture (\%) & 8.50 & 7.20 \\
\hline Crude fat (\%) & 3.20 & 3.20 \\
\hline Crude protein (\%) & 25.42 & 25.49 \\
\hline Total carbohydrates (\%) & 58.10 & 57.30 \\
\hline Crude fibre (\%) & 3.20 & 3.18 \\
\hline Ash (\%) & 3.10 & 3.20 \\
\hline In-vitro protein digestibility (\%) & 81.40 & 82.70 \\
\hline
\end{tabular}

Results indicates that, there was no change in fat content of mothbean. However, there was increase in protein and ash content of mothbean from 25.42 to 25.49 per cent and 3.1 to 3.2 per cent respectively. Increase in protein may be due to uptake of water during sprouting and increase in ash content may be due to the minerals imbibed from water. The carbohydrate content was decreased from 58.1 to 57.3. It may be due to increased activity of carbohydrases. Crude fibre was reduced slightly it may be due to cell wall degradation. The results of the present study are in good accordance as reported by Pawar (1986). IVPD was increased from 81.40 to 82.70 per cent. This may be attributed due to proteolytic digestion which in turn facilitated their easy penetration and absorption. The results reported are in good agreement as that of Ismail et al. (2003) ${ }^{[10]}$.

\section{Dehusking of sesame}

Dehusking of sesame also altered the chemical composition in the form of decrease in crude fibre from 2.40 to 2.20 per cent and ash content from 3.60 to 3.40 per cent (Table 5). The decrease in crude fibre might be result of removal of seed coat rich in fibre content. However, decrease in ash might be due to removal of total minerals at the time of treatment. The results related to sesame are in good accordance with the results reported by Kulkarni (1994) ${ }^{[11]}$.

Table 5: Chemical composition of sesame and dehusked sesame

\begin{tabular}{|c|c|c|}
\hline Constituents & Sesame & Dehusked sesame \\
\hline Moisture (\%) & 5.10 & 4.20 \\
\hline Crude fat (\%) & 45.50 & 45.50 \\
\hline Crude protein (\%) & 22.57 & 22.57 \\
\hline Total carbohydrates (\%) & 26.35 & 26.34 \\
\hline Crude fibre (\%) & 2.40 & 2.20 \\
\hline Ash (\%) & 3.60 & 3.40 \\
\hline
\end{tabular}

\section{Physical characteristics of developed weaning food Particle size}

Particle size is an important feature of any granular mix that required reconstitution with water. The smaller the particle 
size, the more surface area is available for water absorption. A fine powder tends to form more lumps and takes more time and energy to make a good dispersion. Very large particles make the dispersion grittier. An optimum distribution of particle size is essential in order to get the best acceptability. Table 6 indicates the particle size distribution of the weaning food ingredients and formulations. About half of the sorghum malt particles were larger than 250 microns and the rest were smaller. The mothbean malt particles were finer than the sorghum malt and the sesame flour particles were all larger than 250 microns. The commercial weaning food sample had larger particles than the experimental formulations about 78 per cent of the particles were larger than 250 microns. The results are in good accordance with the earlier worker (Kulkarni et al., 1991) ${ }^{[12]}$. The results pertaining to particle size distribution are narrated as in Table 6.

Table 6: Particle size distribution of the weaning food ingredients and formulations (percentages of material retained on the screen)

\begin{tabular}{|c|c|c|c|c|c|c|c|}
\hline \multirow{2}{*}{ Ingredients } & \multicolumn{7}{|c|}{ Sieve size (micron) } \\
\cline { 2 - 9 } & $\mathbf{2 5 0}$ & $\mathbf{2 2 5}$ & $\mathbf{2 0 5}$ & $\mathbf{1 5 0}$ & $\mathbf{1 1 0}$ & $\mathbf{7 5}$ & $\mathbf{6 7}$ \\
\hline Sorghum malt & 50.39 & 5.06 & 7.21 & 30.29 & 2.41 & 3.52 & 0.09 \\
\hline Mothbean malt & 7.42 & 3.42 & 24.54 & 4.42 & 11.61 & 44.94 & 0.50 \\
\hline Sesame flour & 100.00 & --- & --- & --- & --- & --- & --- \\
\hline Formulations & & & & & & & \\
\hline $\mathrm{F}_{1}$ & 40.04 & 12.53 & 10.70 & 11.50 & 6.25 & 18.64 & 0.24 \\
\hline $\mathrm{F}_{2}$ & 37.50 & 12.20 & 9.40 & 18.00 & 5.23 & 16.70 & 0.20 \\
\hline $\mathrm{F}_{3}$ & 38.97 & 14.89 & 8.18 & 20.45 & 4.20 & 12.05 & 0.16 \\
\hline Control & 78.00 & 5.02 & 7.73 & 8.50 & 0.65 & --- & --- \\
\hline
\end{tabular}

\section{Colour}

The colour of the experimental weaning food formulations depends on the colour of the ingredients used. The colour of sorghum malt was white. The mothbean malt was pale yellow and the sesame flour slightly brownish yellow. The colour of the experimental formulations did not vary much (Table 8). The commercial sample was superior in colour as compared to the experimental weaning food formulations. In the present investigation, the results reported by Kulkarni et al. (1991) ${ }^{[12]}$ are matching with results of present study. Weaning food formulations were also evaluated for their bulk density, water absorption capacity and dispersibility. The results related to these physical properties are given in Table 7.
Table 7: Colour of weaning food ingredients and formulations

\begin{tabular}{|c|c|c|}
\hline & Munsell notation & Visual \\
\hline Ingredients & & \\
\hline Sorghum malt & $5 \mathrm{Y} 8 / 2$ & White \\
\hline Mothbean malt & $5 \mathrm{Y} 8 / 4$ & Pale yellow \\
\hline Sesame flour & 10 Y $6 / 8$ & Brownish yellow \\
\hline Weaning food formulation & & \\
\hline $\mathrm{F}_{1}$ & $5 \mathrm{Y} 8 / 2$ & White \\
\hline $\mathrm{F}_{2}$ & $5 \mathrm{Y} 8 / 3$ & White \\
\hline $\mathrm{F}_{3}$ & $5 \mathrm{Y} 8 / 3$ & White \\
\hline Control & $5 \mathrm{Y} 9 / 2$ & White \\
\hline
\end{tabular}

\section{Bulk density, Water absorption capacity and Dispersibility}

The low density and high dispersibility of the foods especially the weaning foods are the desirable properties. The weaning food formulations had low bulk densities $(0.51$ to $0.53 \mathrm{~g} / \mathrm{ml})$ compared to control sample $(0.59 \mathrm{~g} / \mathrm{ml})$. The bulk density of weaning foods was reported as 0.42 to $0.72 \mathrm{~g} / \mathrm{ml}$ by Wondimu and Malleshi (1996) ${ }^{[25]}$. It gives an indication of the amount of water available for gelatinization. Lowest absorption capacity is desirable for making thinner gruels. The sorghum malt and sesame flour had lower absorption capacities than the mothbean malt. The experimental formulations had absorption capacities in the range of 100-130 g/100 $\mathrm{g}$ of sample, while that of the commercial weaning food was significantly higher $(190 \mathrm{~g} / 100 \mathrm{~g})$. Formulation F3 containing 70 per cent sorghum malt, 10 per cent mothbean malt, 10 per cent sesame flour and 10 per cent skim milk powder had the water absorption capacity. Mahgoub (1999) [14] described water absorption capacity for five weaning food formulations in the range of 340 to $410 \mathrm{~g} / 100 \mathrm{~g}$. The results are in good conformity. The dispersibility of a mix in water indicates its re- constitutability. Higher the dispersibility, better the reconstitutability. The percentage dispersibility of the weaning food ingredients ranged 70 to 74 . Sorghum malt and sesame flour indicated same percentage dispersibility i.e., 74 per cent. The weaning food formulations had percentage dispersibility in the range of 68 to 76 per cent. The weaning food formulation containing large quantity of sorghum malt had highest percentage dispersibility. Control sample had very low dispersibility i.e., 56 per cent. The dispersibilities of weaning food ingredients and weaning food formulations are indicated in Table 8. Bhagwat (1986) ${ }^{[5]}$ also reported the dispersibility of weaning food as 72 per cent.

Table 8: Bulk density, dispersibility and water absorption capacity of the weaning food ingredients and weaning foods

\begin{tabular}{|c|c|c|c|}
\hline Ingredients & Bulk density (g/ml) & Dispensability (\%) & Water absorption Capacity (g/100g) \\
\hline Sorghum malt & 0.56 & 74 & 120 \\
\hline Mothbean malt & 0.50 & 70 & 160 \\
\hline Sesame flour & 0.38 & 74 & 110 \\
\hline Formulations & & & 130 \\
\hline$F_{1}$ & 0.53 & 68 & 115 \\
\hline $\mathrm{F}_{2}$ & 0.52 & 72 & 100 \\
\hline $\mathrm{F}_{3}$ & 0.51 & 76 & 190 \\
\hline Control & 0.59 & 56 & \\
\hline
\end{tabular}

Proximate composition of the developed weaning food Weaning foods were analyzed for moisture, protein, fat, ash, crude fibre and carbohydrate content and compared with that of commercial control. The results are given in Table 9.

Table 9: Proximate composition of weaning foods

\begin{tabular}{|c|c|c|c|c|c|c|c|}
\hline \multirow{2}{*}{ Formulation } & \multirow{2}{*}{ Moisture } & \multicolumn{5}{|c|}{ On Dry Weight Basis (\%) } \\
\cline { 3 - 8 } & & Crude Fat & Crude Protein & Total Carbohydrates & Ash & Crude Fibre & Energy Value (Kcal/100g) \\
\hline $\mathrm{F}_{1}$ & 6.82 & 6.75 & 18.42 & 61.24 & 2.61 & 2.02 & 1.90 \\
\hline $\mathrm{F}_{2}$ & 6.84 & 6.68 & 16.87 & 62.67 & 2.49 & 379.39 \\
\hline $\mathrm{F}_{3}$ & 6.90 & 6.63 & 15.45 & 64.17 & 2.29 & 1.78 & 378.32 \\
\hline Control & 2.50 & 9.00 & 15.00 & 67.90 & 3.20 & 2.40 & \\
\hline
\end{tabular}


The moisture content of control was very low i.e., 2.5 per cent as compared to experimental formulations i.e., 6.82 to 6.9 per cent, whereas the fat content of control was high i.e., 9 per cent. Due to the addition of sesame flour the experimental formulations had fat in the range as 6.63 to 6.75 per cent. From the data it is seen that the protein, ash and crude fibre contents were found to be decreased with decrease in mothbean malt. The carbohydrate content was increased with increase in sorghum malt. The gross composition of the three weaning foods used in this study was within the standard limits laid down by the I.S.I standards. The standard limits of I.S.I for moisture maximum 10.0, for protein minimum 14, for fat maximum 75, for ash maximum 5 and for carbohydrate minimum 45, expressed as per cent. The results are in good accordance with the results obtained by Kulkarni et al. (1991) ${ }^{[12]}$. However, Wondimu and Malleshi (1996) ${ }^{[25]}$ compared the proximate composition of the malted, popped and rollerdried weaning food with I.S.I standards. The values of protein, crude fat, total dietary fibre, total ash and carbohydrate were $15.6 \mathrm{~g}, 3.8 \mathrm{~g}, 11.6 \mathrm{~g}, 2.2 \mathrm{~g}$, and $56.5 \mathrm{~g}$, respectively for malted weaning food. Suhasini and Malleshi (2003) ${ }^{[19]}$ also formulated weaning foods based on malted wheat and malted chickpea, popped wheat and popped chickpea and roller-dried blend of wheat and chickpea. The foods contained 16.0 to 17.5 per cent protein, 1.6 to 3.5 per cent fat about 65 per cent available carbohydrates and 9.5 to 10.4 per cent dietary fibre. Control sample indicated highest energy value i.e., $413 \mathrm{Kcal} / 100 \mathrm{~g}$. $\mathrm{F}_{1}$ provided high energy as compared to $\mathrm{F}_{2}$ and $\mathrm{F}_{3}$.

\section{Nutritive value of developed weaning food}

The three weaning food formulations were evaluated for invitro protein digestibility, in-vitro starch digestibility, calcium, phosphorus, iron and available lysine and the results are presented in Table 10.

Table 10: Nutritive value of weaning food

\begin{tabular}{|c|c|c|c|c|c|c|c|}
\hline Formulation & $\begin{array}{c}\text { IVPD } \\
(\boldsymbol{\%})\end{array}$ & $\begin{array}{c}\text { IVSD } \\
(\mathbf{M g} \text { maltose/g/2hr. })\end{array}$ & $\begin{array}{c}\text { Calcium } \\
(\mathbf{m g} / \mathbf{~ 1 0 0 g})\end{array}$ & $\begin{array}{c}\text { Phosphorus } \\
(\mathbf{m g} / \mathbf{1 0 0} \mathbf{g})\end{array}$ & $\begin{array}{c}\text { Iron } \\
(\mathbf{m g} / \mathbf{1 0 0} \mathbf{g})\end{array}$ & $\begin{array}{c}\text { Ascorbic acid } \\
(\mathbf{m g} / \mathbf{1 0 0 g})\end{array}$ & $\begin{array}{c}\text { Available lysine } \\
(\mathbf{g} / \mathbf{1 6} \mathbf{g} \mathbf{~})\end{array}$ \\
\hline $\mathrm{F}_{1}$ & 82.40 & 129 & 369.5 & 385.5 & 9.15 & 25.89 & 3.87 \\
\hline $\mathrm{F}_{2}$ & 80.93 & 133 & 350.2 & 380.0 & 8.95 & 22.98 & \\
\hline $\mathrm{F}_{3}$ & 80.23 & 135 & 330.9 & 374.5 & 8.75 & 18.99 & 3.83 \\
\hline Control & 80.00 & 125 & 480.0 & 370.0 & 10.00 & 50.00 & 3.79 \\
\hline
\end{tabular}

It was found that experimental formulation containing high amount of mothbean malt had high IVPD. Table 11 gives the IVPD values in the range of 80.23 to 82.40 per cent. These values were higher because of increase in soluble proteins and free amino acids produced due to partial hydrolysis by endogenous enzymes during malting, such proteins are more easily available for pepsin attack (Bhise et al., 1988) ${ }^{[6]}$. The control sample had low IVPD as compared to experimental formulations i.e., 80 per cent. The IVSD increased with increase in sorghum malt. It was due to hydrolysis of starch into reducing sugars and non-reducing sugars by amylases during malting (Chavan and Kadam, 1989) ${ }^{[8]}$. The IVSD values of experimental formulations were in the range of 129$135 \mathrm{mg}$ maltose /g/ $2 \mathrm{hr}$. The control had lower IVSD i.e., 125 as compared to experimental formulations. Results of this study are also similar to the results reported by Bodhankar $(1992)^{[7]}$.

The calcium content of the three experimental formulations was in the range of 330.9 to $369.5 \mathrm{mg} / 100 \mathrm{~g}$. Calcium content was higher compared to malt based weaning food developed by Wondimu and Malleshi (1996) ${ }^{[25]}$. It was due to addition of sesame being rich source of calcium. The phosphorus content of the formulations was higher i.e., 374.5 to 385.5 $\mathrm{mg} / 100 \mathrm{~g}$ as compared to control i.e., $370 \mathrm{mg} / 100 \mathrm{~g}$. The iron content of formulations was found in the range of 8.75 to 9.15. The iron content of control was $10 \mathrm{mg} / 100 \mathrm{~g}$ which was higher than experimental formulation. The calcium, phosphorous and iron content of the experimental formulations increased with increase in mothbean malt.

The ascorbic acid content of the experimental formulations was found in the range of 18.99 to $25.89 \mathrm{mg} / 100 \mathrm{~g}$. There was increase in ascorbic acid content with increase in mothbean malt. Control contained $50 \mathrm{mg} / 100 \mathrm{~g}$ of ascorbic acid. Formulations with higher proportions of mothbean malt and sesame flour yields good amount of available lysine. Experimental formulations had higher available lysine i.e., 3.79 to $3.87 \mathrm{~g} / 16 \mathrm{~g}$ N than control i.e., $3.7 \mathrm{~g} / 16 \mathrm{~g} \mathrm{~N}$.

\section{Rheological characteristics of developed weaning foods}

Hot and cold paste viscosities of the weaning foods were determined by using Haake's Rotoviscometer (Model RV20).

\section{Hot paste viscosity}

The hot paste viscosities of the weaning food formulations at 15 per cent slurry concentrations are shown in Table 12. control weaning food had significantly higher hot paste viscosities i.e., 426.85 and $65.10 \mathrm{~m}$.pa.s at 4.62 and $161 \mathrm{sec}^{-1}$ shear rates respectively. Whereas the formulation $F_{3}$ containing high amount of sorghum malt had minimum viscosity values i.e., 54.75 and 17.00 m.pa.s at 4.62 and 161 $\mathrm{sec}^{-1}$ shear rates respectively. This is expected as the sorghum malt has higher amylolytic activities causing starch hydrolysis (Chavan and Kadam, 1989) ${ }^{[8]}$. It was found that as the shear rate increased, the hot paste viscosity decreased.

Table 11: Hot paste viscosities of weaning food

\begin{tabular}{|c|c|c|c|c|c|}
\hline \multirow{3}{*}{ Formulation } & \multicolumn{5}{|c|}{ Apparent viscosity m.pa.s } \\
\cline { 2 - 6 } & \multicolumn{5}{|c|}{ Shear rate (sec $^{-1}$ ) } \\
\cline { 2 - 6 } & $\mathbf{4 . 6 2}$ & $\mathbf{7 . 6 6}$ & $\mathbf{2 0 . 9 9}$ & $\mathbf{5 8 . 2}$ & $\mathbf{1 6 1}$ \\
\hline Control & 426.85 & 128.37 & 98.88 & 78.01 & 65.10 \\
\hline $\mathrm{F}_{1}$ & 56.92 & 40.21 & 30.51 & 23.07 & 18.41 \\
\hline $\mathrm{F}_{2}$ & 55.89 & 39.32 & 30.01 & 22.99 & 17.99 \\
\hline $\mathrm{F}_{3}$ & 54.75 & 38.91 & 31.04 & 21.01 & 17.00 \\
\hline
\end{tabular}

\section{Cold paste viscosity}

The values for cold paste viscosity are narrated in Table 12. The cold paste viscosities were high as compared to hot paste viscosities. Because the residual starch retrogrades on cooling and takes up much more water, making it viscous. The experimental formulations had significantly lower cold paste viscosities as compared to the commercial sample. Commercial sample recorded maximum cold paste viscosities i.e., 520.32 and 71.48 at 4.62 and $161 \mathrm{sec}^{-1}$ shear rates. Weaning food formulations F1, F2 and F3 recorded cold paste 
viscosities in the range of the 80.88 to $21.01,80.00$ to 20.39 and 78.22 to 19.01 m.pa.s respectively at 4.62 to $161 \mathrm{sec}^{-1}$ shear rates.

Table 12: Cold paste viscosities of weaning food

\begin{tabular}{|c|c|c|c|c|c|}
\hline \multirow{3}{*}{ Formulation } & \multicolumn{5}{|c|}{ Apparent viscosity m.pa.s } \\
\cline { 2 - 6 } & $\mathbf{4 . 6 2}$ & $\mathbf{7 . 6 6}$ & $\mathbf{2 0 . 9 9}$ & $\mathbf{5 8 . 2}$ & $\mathbf{1 6 1}$ \\
\hline Control & 520.32 & 328.13 & 138.39 & 93.53 & 71.48 \\
\hline $\mathrm{F}_{1}$ & 80.88 & 57.21 & 36.98 & 28.45 & 21.01 \\
\hline $\mathrm{F}_{2}$ & 80.00 & 57.01 & 35.25 & 27.10 & 20.39 \\
\hline $\mathrm{F}_{3}$ & 78.22 & 56.14 & 34.12 & 26.00 & 19.01 \\
\hline
\end{tabular}

\section{Organoleptic evaluation of developed weaning foods}

The weaning food formulations were subjected to the organoleptic evaluation by semi trained judges, and infant's mothers. Semi trained judges and infant's mothers rated for the evaluation of colour, flavour, taste, consistency and overall acceptability using 9 point hedonic scale. The colour of the formulation containing high amount of sorghum malt was good as compared to other (Table 13). Weaning food prepared with different formulations were subjected to organoleptic evaluation. The results are presented in Table 14. Weaning food F1 and F2 were at par with the control for colour, flavour and taste. Whereas F1, F2 and control were significantly superior over F3 for colour, flavour and taste. All the experimental weaning food formulations scored significantly higher than the control sample for consistency. This was due to high amylolytic activity of malted weaning food. Weaning food F1 and F2 were at par with control for overall acceptability. Weaning food F1 rated higher scores for colour, flavour, taste, consistency and overall acceptability followed by control and F2.

Table 13: Organoleptic evaluation of weaning food

\begin{tabular}{|c|c|c|c|c|c|}
\hline Formulation & Colour & Flavour & Taste & Consistency & Overall acceptability \\
\hline $\mathrm{F}_{1}$ & 8.28 & 8.28 & 8.28 & 8.27 & 8.28 \\
\hline $\mathrm{F}_{2}$ & 8.00 & 7.57 & 8.14 & 8.28 & 7.42 \\
\hline $\mathrm{F}_{3}$ & 6.57 & 6.28 & 6.42 & 8.29 & 5.64 \\
\hline Control & 8.00 & 8.14 & 8.10 & 6.10 & 8.08 \\
\hline S.E. + & 0.42 & 0.51 & 0.50 & 0.52 & 0.54 \\
\hline CD at 5\% & 1.16 & 1.41 & 1.38 & 1.45 & 1.50 \\
\hline
\end{tabular}

\section{Conclusion}

Three weaning foods combination were prepared by using different proportions of sorghum malt flour, mothbean malt flour, sesame flour and skim milk powder. These formulations were subjected to organoleptic evaluation and among the experimental formulations, formulation $F_{1}$ containing sorghum malt, mothbean malt, sesame flour and skim milk powder in the proportion of 50:30:10:10 was accepted as best considering the highest sensory score (8.28) awarded to it.

\section{References}

1. AOAC. Official Methods of Analysis. Trends Food Science Technology. Association of Official Analytical Chemists, Washington, DC, USA 1990.

2. AOAC. Methods of analysis, 17th ed. Association of official Analytical Chemists, Washington, DC 2000.

3. AOAC. Official methods of analysis $18^{\text {th }}$ edition, association of official analytical chemists, Washington DC, USA 2003.

4. Berggren GG. Questions and answers about weaning. Food Nutr. Bull 1982;4(1):20-24.

5. Bhagwat SM. Studies on malt based weaning foods. M.Tech. (Food Sci.) Thesis, Marathwada Agriculture University, Parbhani (M.S.), India 1986.

6. Bhise VJ, Chavan JK, Kadam SS. Effect of malting on proximate composition and invitro protein and starch digestibility of grain sorghum. Journal of Food Sci. Technol 1988;25(6):327-329.

7. Bodhankar SS. Preparation and qualities of weaning food. Thesis (M.Tech), M.A.U., Parbhani (M.S.), India 1992.

8. Chavan JK, Kadam SS. Nutritional improvement of cereals by sprouting critical reviews in Food Science and Nutrition 1989;28(5):401-433.

9. Gopalan C, Ramasastri BV, Balasubramanian. Nutritive value of Indian Foods. National Institute of Nation, Hyderabad 2002.
10. Ismail, Wankhede DB, Syed HM, Kulkarni AS, Fayazuddin M. The effect of germination on the changes in protein, free amino acid and In vitro protein digestibility of moth bean and horsegra. In : Advances in Arid Legumes Research (Henry et al. eds). India Arid Legumes Society, Scientific Publishers, Jodhpur (India) 2003, 315-317.

11. Kulkarni KD. Studies on sorghum grain quality in relation to malting and brewing. Thesis (Ph.D.) M.A.U., Parbhani (M.S.), India 1994.

12. Kulkarni KD, Kulkarni DN, Ingle UM. Sorghum malt based weaning food formulations: Preparation, functional properties and nutrition Bulletin. 1991;13(4):322-327.

13. Laxmi Tulasi. Performance of broilers on diets containing certain improved sorghum cultivars (sorghum bicolor). M.V.Sc Thesis, submitted to Acharya N.G. Ranga Agricultural University, Rajendranagar, Hyderabad, Andhra Pradesh, India 2003.

14. Mahgoub SEO. Production and evaluation of weaning foods based on sorghum and legumes. Plant Foods for human Nutr 1999;54:29-42.

15. Malleshi NG, Desikachar HSR. Studies on omparative malting characteristics of same tropical cereals and millets. J. Inst. Brew 1986;92:174-176.

16. Malleshi NG, Daodu MA, Chandra Sekhar A. Development of weaning food formulations based on malting and roller drying of sorghum and cowpea. Int. J. of Fd. Sci. and Technol 1989;24:511-519.

17. Malleshi NG, Raghavendra Rao SN, Sreedharamurthy S, Desikachar HSR. Development of weaning Foods bassed on some traditional technologies. $\mathbf{J}$ of Food Sci. and Technol 1986;23:315-318.

18. Panse VG, Sukhatme PV. Statistical methods for agricultural workers. Second edition, ICAR, New Delhi 1985.

19. Suhasini AW, Malleshi NG. Self-selection trials of wheat and chickea based weaning foods on weaning rats. J Food 
Sci. Technol 2003;40(5):468-471.

20. Swaminathn M. "Food and Nutrition", Banglore, the Banglore Printing and publishing Co. Ltd 1996;II:9.

21. Syed Ismail, Kulkarni PJ, Borikar ST. Variability in nutritional composition and roti making quality trails in sorghum. International sorghum and millets Newsletter 2000;41:56-58.

22. Tokusoglu O, Unal MK, Alakir I. Proximate chemical composition, amino acid and fatty acid profiles of sesame seed flours. J Fd. Sci. and Technol 2004;41(4):409-412.

23. Wankhede DB, Antwal MM, Syed Ismail, Kulkarni AS, Patil HB. Use of sorghum starch maltodextrin as a fat replacement in low calorie food stuffs, Int. sorghum and millets Newsletter No. 2000;41:56.

24. Wankhede DB. Annual research progress Report (quality) of All India Cordinated Research Project on Arid Legumes, Presented in XXI Annual Arid Legumes. Workshop, held at regional Agricultural Research Station, Tirupati 2005.

25. Wondimu A, Malleshi NG. Development of waning foods based on malted, popped and roller-dried barley and chickpea. Food and Nutr. Bulletin 1996;17(2):169176.

26. Wu YV, Wall JS. Lysine content of protein increased by germination of normal and high lysine sorghums. J Agric. Food Chem 1980;28:455-458. 